\title{
The internal structure of Paleoal pine thrusts of the Western Carpathians: A case study from the Križná thrust system
}

Peter Kováč

Geological Institute, Slovak A cademy of Sciences, Bratislava

The aim of this article is to point out the complicated internal structure of Paleoalpine thrusts of the Western Carpathians and the consequential ambiguous interpretations of the tectonic transport of these tectonic units. The example used here is that of the internal structure of the Križná thrust system in the area of the Demänová and II'anová Valleys in Nízke Tatry Mountains.

The form that the Križná thrust takes is that of three individual thrust sheets. These overthrust each other along differently oriented thrust ramps. The geometry of the ramps influences the direction of the thrust displacement of the individual thrust sheets of the Križná thrust.

Key words: Western Carpathians, thrust tectonics, thrust ramp geometry

\section{Introduction}

Thrust sheets are generally composed of incompetent and competent horizons forming a brittle-ductile multi-layer system. Upon shortening, this system develops thrust faults, characterized by ramp-flat geometry; with the flats commonly localized along the incompetent horizons and the ramps cutting upsection through the competent layers (Dahlstrom 1970; Elliott 1976; Boyer and Elliot 1982; Butler 1982; Eisenstadt and De Paor 1987) (Fig. 1).

Incompetent beds, e.g. shale, represent the preferred detachment layer for emplacement of the thrust sheets (Boyer and Elliot 1982). The creation of thrust ramps has been described in detail in different collision mountain belts (Suppe 1983).

Address: P. Kováč: Dúbravska cesta 9, 84006 Bratislava, Slovakia, e-mail: geol peto@gmail.com Received: December 12, 2005, accepted: September 28, 2006 


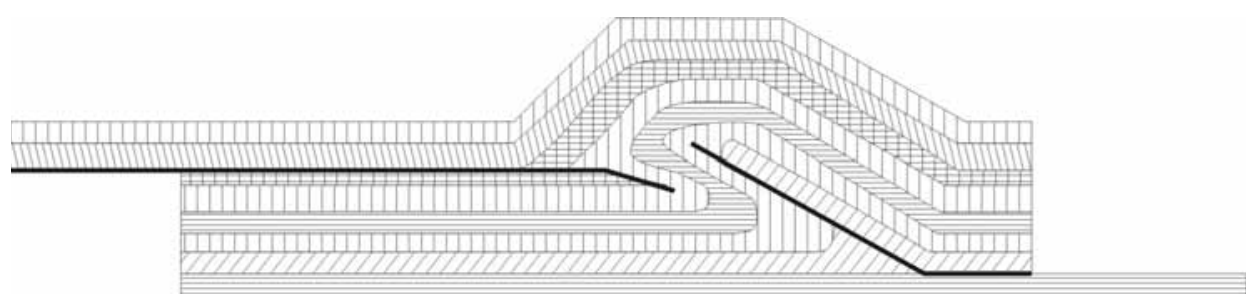

Fig. 1

The ramp-flat geometry of the thrust (Apotria 1988). Thrust displacement transfers through faults, as well as folds, which were created as a result of thrusting

Thrust ramps can be divided according to the geometry of footwall thrust sheets into frontal, lateral and oblique ones (Fig. 2).

The thrusting direction along the frontal thrust ramps matches the direction of the overall tectonic transport, as do fault-propagation folds, which were formed as of result of this process. The thrusting is parallel to the dip of the frontal ramps.The movement along lateral ramps is basically strike-slip.

If thrust segments change the trend of thrusting to become oblique to the overall transport direction, then most probably an oblique ramp exists (e.g. Apotria et al. 1992; Apotria 1995; Apotria and Wilkerson 2002). The existence of oblique ramps is connected with a change in the morphology of the underlying basement (Apotria 1995). The direction of the thrusting depends on the strikeand dipping of the oblique thrust ramp with respect to the direction of thrusting. Folds and faults develop at an angle to the overall transport direction, commonly with the fold axes parallel to the strike of the lateral/oblique footwall ramp (Apotria 1995). The thrust sheet rotation associated with oblique ramps has been documented in numerous studies (Dinares et al. 1992; Jolly and Sheriff 1992).

Fig. 2

Diagram of the footwall thrust. The frontal, oblique and lateral thrust ramps are marked (Wilkerson and Marshak 1997)

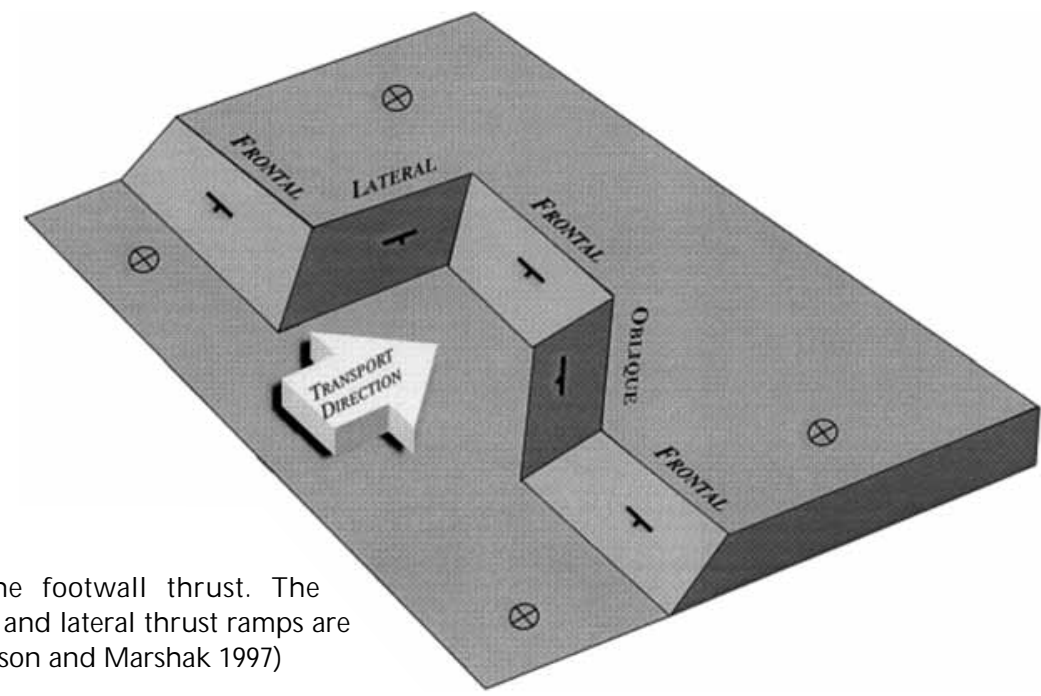




\section{The Križná thrust and its position in the Paleoalpine thrust system of the Western Carpathians}

The Western Carpathians is a southeast to northwest-vergent fold and thrust belt that developed as a result of orogenic shortening within the framework of the Paleoalpine tectonic event (Andrusov 1936, 1959, 1960; Mahel' 1986) (Fig. 3). Several stacked major thrust sheets were generated and thrusted over each other (Fig. 4).

The Križná thrust system is one of these major Paleoalpine tectonic units. It is a widespread (approx. $250 \times 50 \mathrm{~km}$ ), but comparatively thin (approx. 1-3 km) system of individual thrust segments (Fig. 3) (Plašienka 1999). These consist of numerous dismembered slices, duplexes and recumbent folds. The direction of the thrusting is generally to the northwest (Uhlig 1903, 1907; Andrusov and Matějka 1931; Andrusov 1959, 1960; Mahel' et al. 1967). A crystalline basement sporadically occurs at the base of the individual thrust sheets (Jaroš 1971). Lithological sequences of Mesozoic rocks of the Križná thrust system are generally divided into two types of sedimentary successions (Mahel' et al. 1967). The first, most widespread type is composed of deep marine Jurassic-Cretaceous sediments representing the basinal part of the primary sedimentary area. The second type comprises sequences of shallow-marine Jurassic sediments, which constituted northern and southern marginal parts of this sedimentary basin. The southern marginal zone represents the Vel'ký Bok Sequence, which is not detached from its original basement, represented by the Veporic crystalline complex (Andrusov 1959; Mahel' 1986)

\section{Geologic structure of the Križná thrust in the Demänová and II'anová Valleys}

The geometry of individual thrust segments of the Križná thrust has been studied in the Nízke Tatry Mountains, in the Demänovská and Il'anová Valleys.

The geologic structure of the studied area is built by Hercynian crystalline rocks and Early Triassic sediments of the Tatricum Unit, Mesozoic sediments of the Križná thrust, and Mesozoic sediments of the Hronicum thrust (Biely et al. 1997).

The complicated tectonic structure of the Križná thrust in the Demänovská Valley was already studied by Kettner (1927). He proposed the existence of recumbent folds or individual thrusts there. Kettner (I.c.) recognized two thrusts of the Križná Unit eastward of the Demänovská Valley, in the area of Krakova hol'a. The first one, named "the Bystrá Digitation", consists of Triassic and Jurassic-Cretaceous sediments. The second one, the tectonic unit in the footwall, was considered as the main tectonic unit of the Križná thrust.

Later, Biely (in Biely et al. 1997) described two apparent folds in this area. According to him, "the Bystrá Digitation" is also part of the Križná thrust. The thrusting direction has not been studied in detail. 


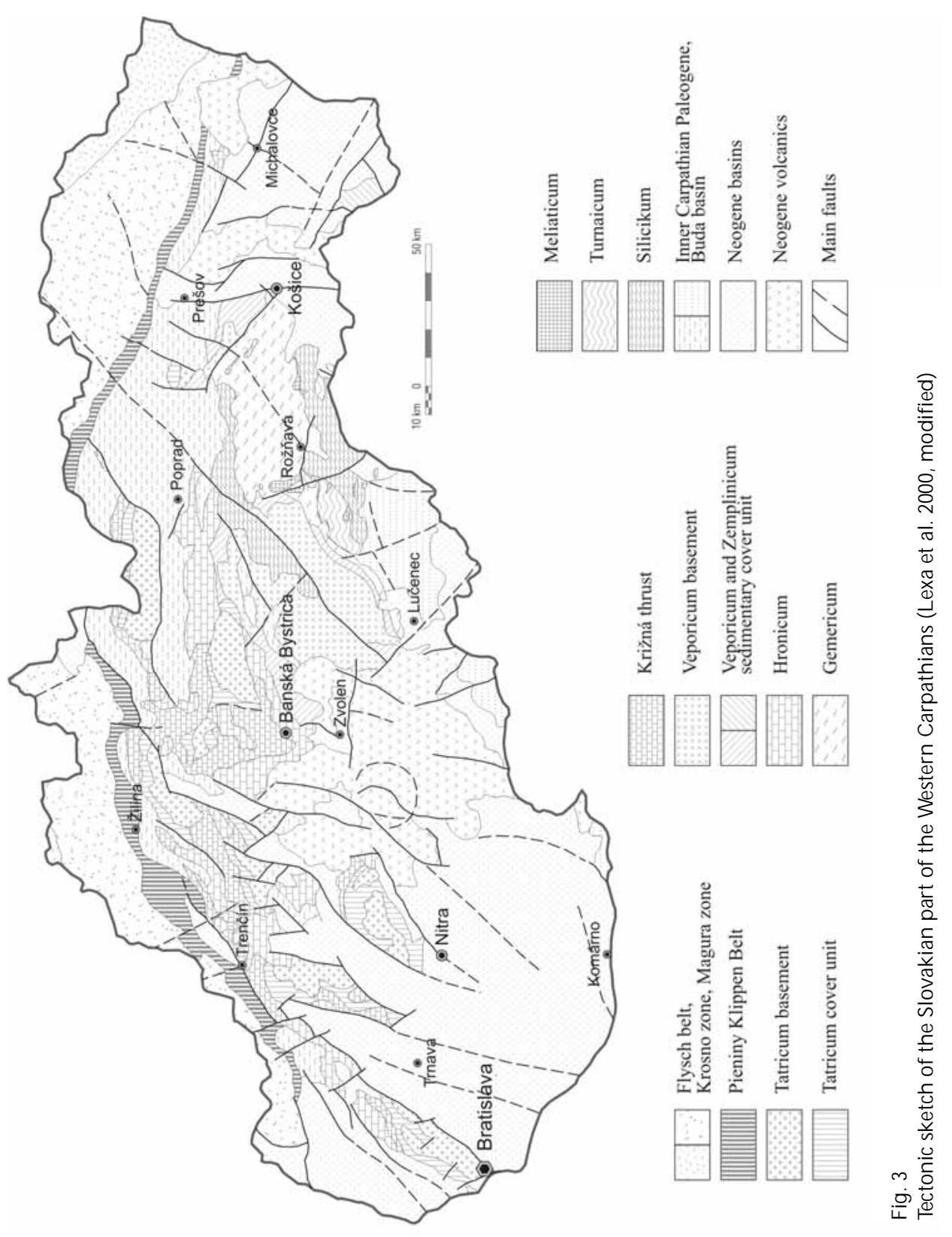

Central European Geology 50, 2007 


\section{Lithology and stratigraphy}

A shallow water marginal sequence of the Križná thrust - the Il'anová Sequence (Fig. 5) - occurs at the northern slopes of the Nízke Tatry Mountains, in the area of the Demänová and Il'anová Valleys (Kettner 1927). Its stratigraphic range is Rhaetian to Berriasian (Mahel' et al. 1967; Kulmanová et al. 1983). The Triassic shallow-water sediments of the sequence change laterally both easterly and westerly to the deep water members of the Zliechov Sequence of the Križná thrust.

The relationship of overlying Jurassic beds of those two sequences is ambiguous, due to the existence of an elevation, the upper part of which has been eroded (Kettner 1931; Biely et al. 1997).

The Triassic is built up at the base by fine-grained, solid Gutenstein Limestone with dolomite intercalations. It is overlain by bedded, partly solid Ramsau Dolomite with lenses of dark organodetritic limestone. Ramsau Dolomite, with layers of black bedded limestone, occurs on the eastern side of the Demänová Valley. This Ramsau Dolomites is overlain by variegated, bedded, clay-dolomite. The dolomite hosts intercalations of variegated clay and dolomitic shale and lenses and clusters of gray, white and red chert (Biely et al. 1997). The lower part of the Upper Triassic is composed of clay / shale with intercalations of sandstone and dolomite of the Carpathian Keuper Beds. The upper part of the Upper Triassic is represented by the Kössen

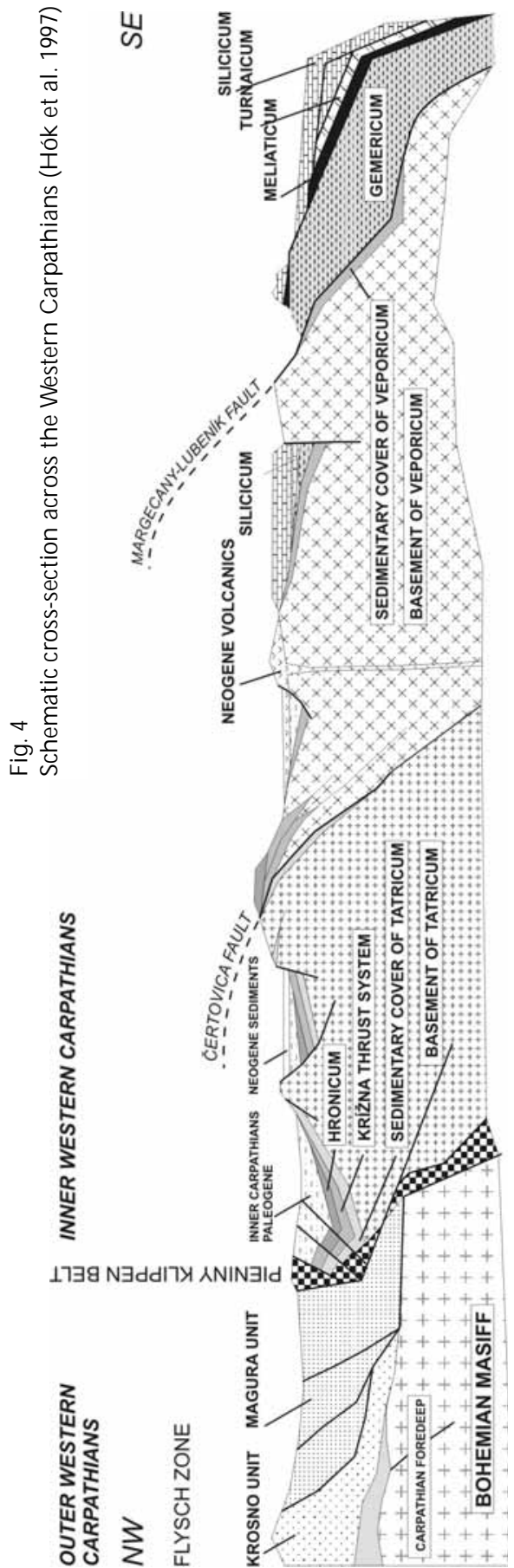


Beds, which consist of organodetritic and clastic limestone. They are the product of shallow water sedimentation.

The Jurassic members of the Il'anová Sequence occur between the Demänová and Jánska Valleys. In this area the Il'anová Sequence was studied in detail by Kulmanová et al. (1983). The lithostratigraphic sections in the area of Demänovská Magura and Krakova hol'a are described here. The Demänovská Magura section consists of the lithostratigraphic sequence ranging from Rhaetian to Berriasian. The Kraková hol'a profile is incomplete and it comprises only the uppermost part of the Jurassic-Lower Cretaceous sequence.

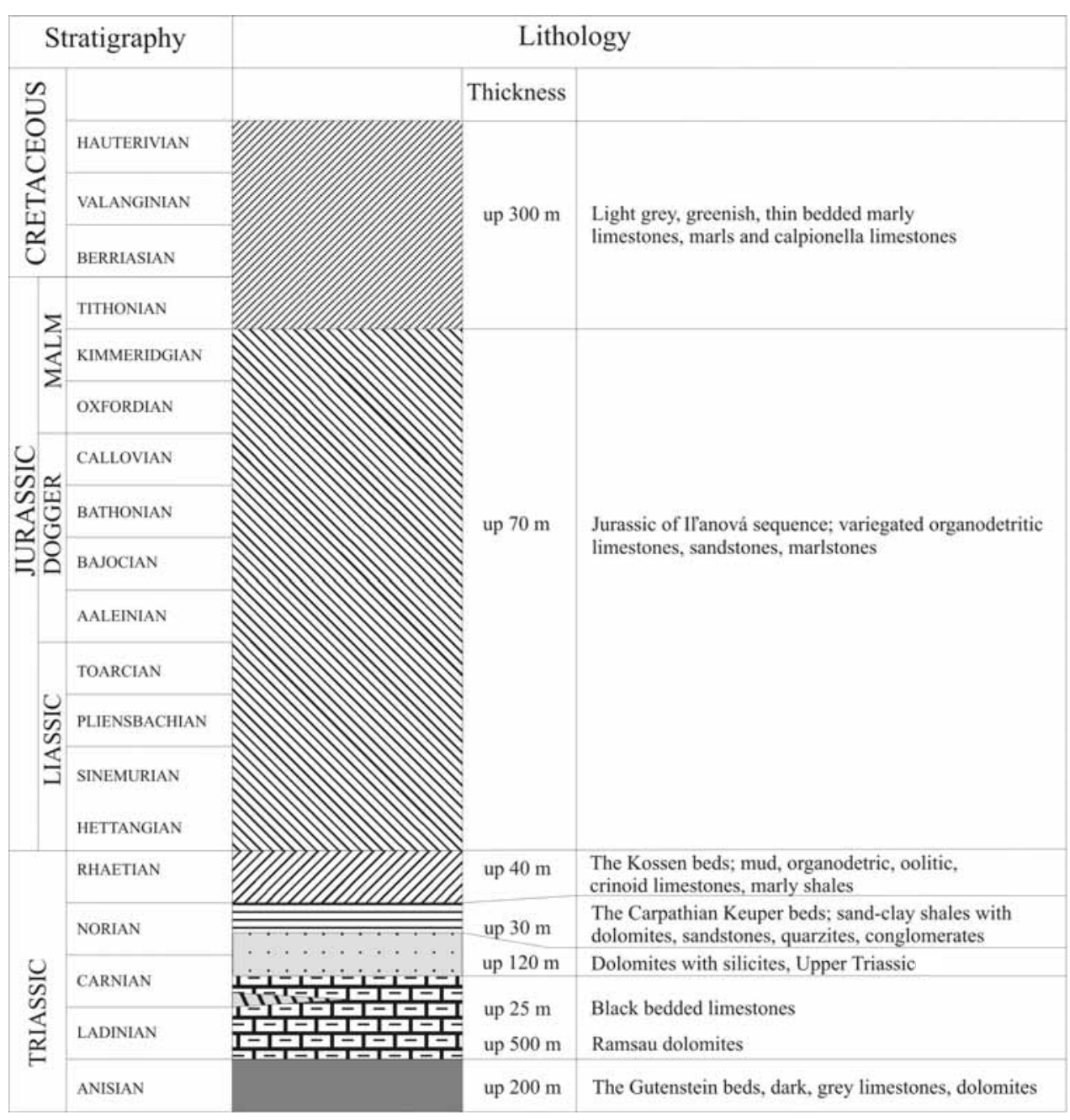

Fig. 5

Schematic lithostratigraphic table of the Krizná thrust in the Demänová and II'anovská Valleys 
The lowermost part of the Jurassic sedimentation, which conformably overlies the Upper Triassic Kössen Beds, consists of gray, dark gray, fine-grained sandy limestone and calcareous sandstone. They are interbedded with dark gray clay marlstone. The marlstone content decreases upward and it continuously alternates with brown-red sandy crinoid limestone. Beds of oolitic limestone, lummachelle limestone and cross-bedding structures are also described here.

The overlying lithostratigraphic member is represented by red and green, slightly nodular, bedded organodetritic limestone and fine-grained biomicritic limestone with red chert and intraformational breccia. It is overlain by variegated bedded limestone with chert. The most distinctive lithostratigraphic member of the sequence is Hierlatz-type pink, red and light gray crinoid limestone. The uppermost part of the Jurassic part of the sequence consists of "Ammonitico rosso"-type, variegated nodular limestone and slaty clay limestone and marlstone.

The Early Cretaceous is made up of light gray, greenish, thin-bedded marly limestone, marl and calpionella limestone.

\section{Tectonic structure}

One of the main tectonic units in the area of the Demänová and II'anová Valleys is the Križná thrust. The thrust consists of three individual folded thrust sheets, overthrusting each other (Fig. 6). They form several asymmetrical recumbent folds, associated with numerous secondary minor anticlines and synclines (Fig. 7A). Rare occurrence of tectonic breccia on detachment planes of the individual thrusts indicates low degree of mechanical deformation during thrusting. There is no evidence that the folding mechanism has resulted in foldaxis parallel transport (e.g. sheath folds). The overall character of the thrusting mechanism indicates the minimal degree of metamorphism.

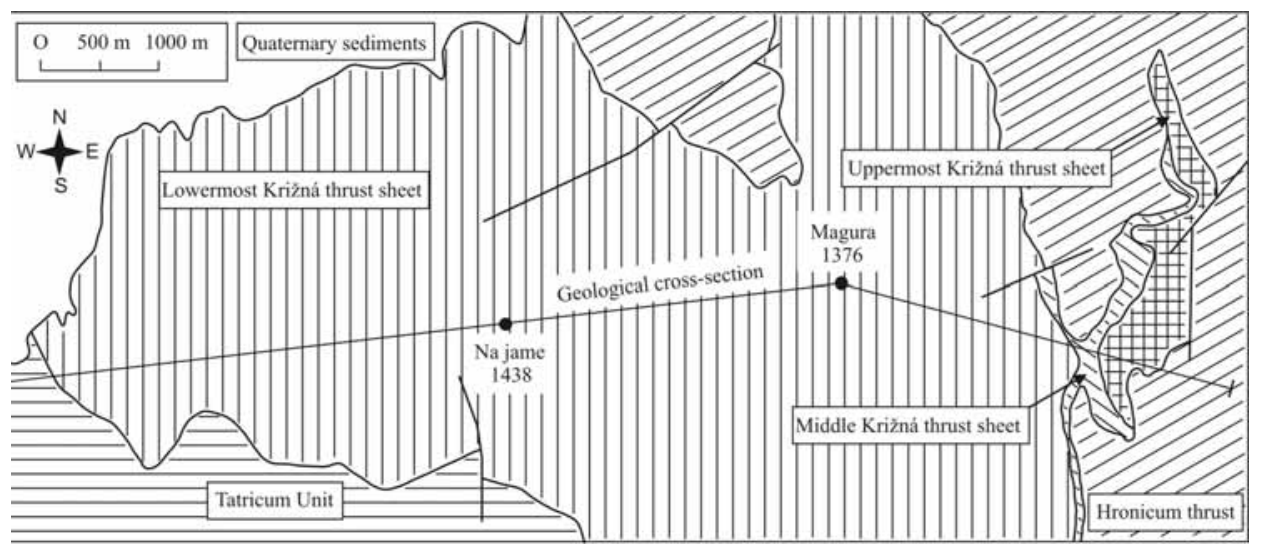

Fig. 6

Tectonic sketch of the Krizná thrust sheets in the Demänovská and II'anovská Valleys (Biely et al. 1992, modified) 


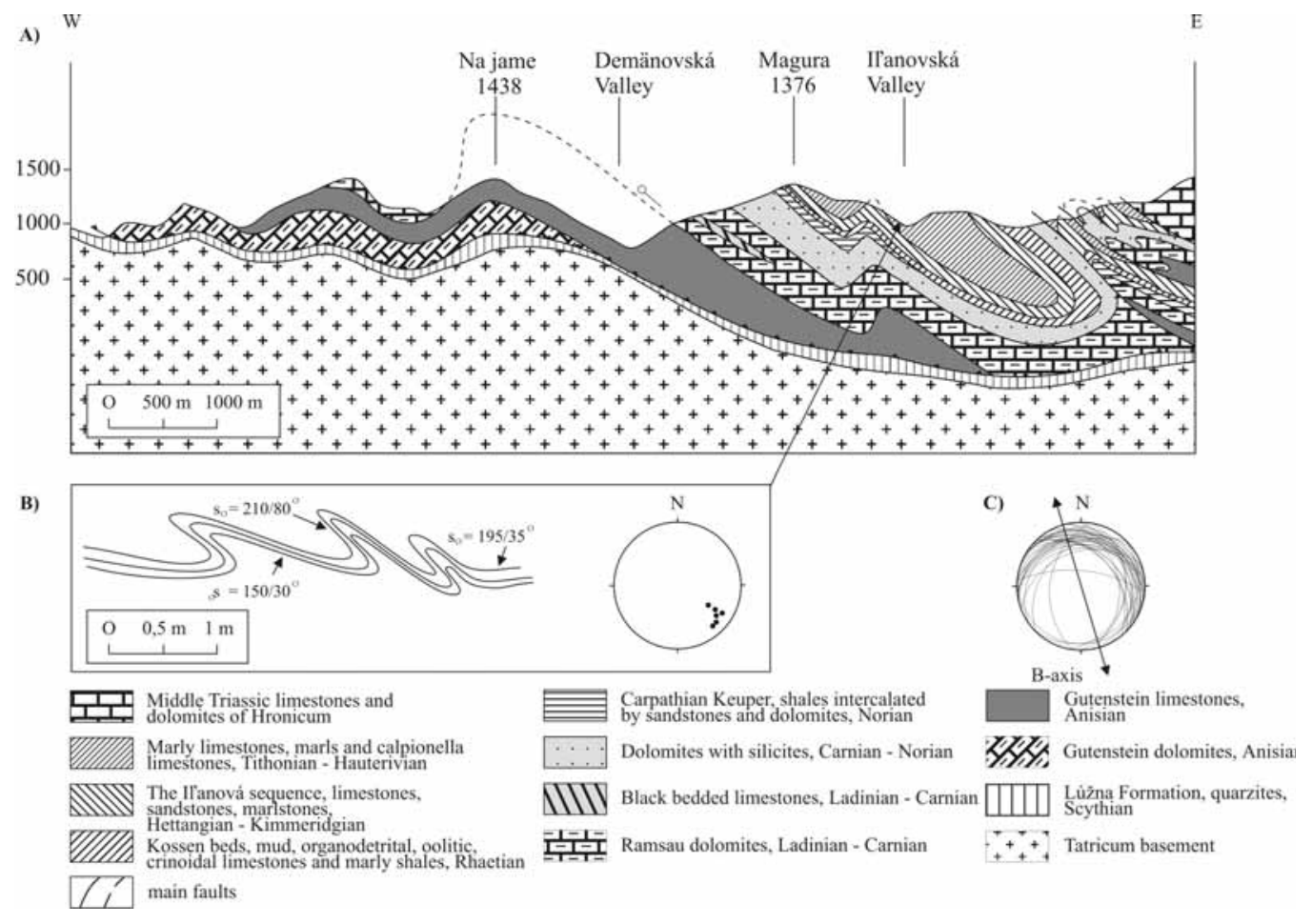

Fig. 7

The Križná thrust system in the Demänovská and II'anovská Valleys, Nízke Tatry Mountains. A) Geologic cross-section. B) Folded Tithonian-Hauterivian marly limestone of the Krizná thrust. B-axis of folds are represented by points and shown by stereographic projection (Schmidt net, lower hemisphere). Fold axes plunge to the southeast (12 measurements). C) Bedding planes of the sediments of the Krizná thrust. Bedding planes are represented by great circles and shown in stereographic projection (Schmidt net, lower hemisphere). Statistic evaluation of the bedding planes shows N N W-SSE oriented B-axes of folds (67 measurements)

The folds of Tithonian-Hauterivian marly limestone in thell'anová Valley were studied (Fig. 7B) as well as the orientation of the bedding planes of the individual thrusts of the Križná Unit in the entire area of the Demänová and II'anová Valleys. Fold axes of marly limestone in the Il'anová Valley plunge to the northwest. The stereographic projection of bedding planes of sediments of individual Križná thrusts indicates fold structure (Fig. 7C). The axis of this structure is oriented NNW-SSE. The asymmetrical character of folds and the orientation of the fold axis suggest a west-southwest trending movement.

The overall orientation of tectonic transport of the Križná thrust in theWestern Carpathians is to the northwest (Uhlig 1903, 1907; Andrusov 1959, 1960; Mahel' et al. 1967; Mahel' 1986). The orientation of the thrusting of the individual thrusts of the Križná Unit in the area of the Demänová and Il'anová Valleys is 
approximately west-southwest. The angle between overall thrusting and thrusting in the studied area is $60-70^{\circ}$. Two explanations for this difference are proposed: firstly, the existence of oblique thrust ramps could cause a different direction of thrusting, and secondly, the thrusting of the Križná thrust in the Demänová and Il'anová Valleys could be the result of another tectonic event, unlike the Paleoal pine thrusting of the Križná thrust.

During the Tertiary, subsequent tectonic events affected the tectonic structure of the studied area. A paleomagnetic rotation has been proven in the area of the Nízke Tatry Mountains. The magnitude of Tertiary counter-clockwise rotation was approximately $20^{\circ}$ (Kruczyk et al. 1992). This rotation could have modified the angle between the overall direction of tectonic transport of the Križná Unit and the thrusting of its individual thrusts in the Demänová and II'anová Valleys.

\section{Conclusion}

The Križná thrust system is one of the main Paleoalpine tectonic units in the Western Carpathians. Its tectonic structure represents an intricate fold and fault thrust system. The Križná Unit consists of three folded thrusts in the area of the Demänová and II'anová Valleys. The direction of thrusting here is to the westsouthwest. This orientation is different from the overall tectonic movement of the Križná thrust, which has been previously described in numerous parts of the Western Carpathians. The angle between overall thrusting and the thrusting in the studied area is approximately $60-70^{\circ}$. The most probable explanation for this is the existence of oblique ramps, which were created in the process of thrusting.

\section{References}

Andrusov, D 1936: Subtatric thrusts of western Carpathians. - Geol. Carpatica, pp. 3-50.

Andrusov, D 1959: Geology of Czechoslovak Carpathians, 2. - Slovak Academy of Science Publisher, Bratislava, $496 \mathrm{p}$.

Andrusov, D 1960: Debate of Alps-Carpathians thrust and fold belt. - Geol. Sbor. 11, pp. 161-178.

Andrusov, D., A. Matějka 1931: Tectonic map of Western Carpathians of the Central Slovakia (sheet Banska Bystrica). - State Geological Institute of Czechoslovakia Publisher, Vol. 13.

Apotria, T.G. 1988: The Kinematics and Mechanics of Oblique Ramp Deformation within Fold and Thrust Belts. - Ph.D. Dissertation, Texas A M University, pp. 1-126.

Apotria, T.G. 1995: Thrust sheet rotation and out-of-plane strains associated with oblique ramps: An example from the Wyoming salient, USA. - Journal of Structural Geology, 17, pp. 647-662.

Apotria, T.G., M.S. Wilkerson 2002: Seismic expression and kinematics of a fault-related fold termination: Rosario Structure, Maracaibo Basin, Venezuela. - Journal of Structural Geology, 24, pp. 671-687.

Apotria, T.G., W.T. Snedden, J.H. Spang, D.V. Wiltschko 1992: Kinematic model of deformation at an oblique ramp. - In: McClay, K.R. (Ed.): Thrust Tectonics. Chapman Hall, London. pp. 141-154.

Biely, A., A. Bujnovský, A. Vozárová, A. Klinec, O. Miko, R. Halouzka, J. Vozár, P. Beňuška, V. Bezák, V. Hanzel, P. Kubeš, P. Lišcák, E. Lukáčik, J. Maglay, B. Molák, M. Pulec, M. Putiš, M. Slavkay 1992: Geological map of the Nízke Tatry Mountains 1: 50 000. - Geological Institute of Dionýz Štúr Publisher, Bratislava.

Biely, A., A. Bujnovský, A. Vozárová, A. Klinec, O. Miko, R. Halouzka, J. Vozár, P. Benuška, V. Bezák, V. Hanzel, P. Kubeš, P. Liščák, E. Lukáčik, J. Maglay, B. Molák, M. Pulec, M. Putiš, M. Slavkay 
1997: Explanation to the geological map of the Nízke Tatry Mountains 1: 50 000. - Geological Institute of Dionýz Štúr Publisher, Bratislava, $232 \mathrm{p}$.

Boyer, M., D. Elliot 1982: Thrust systems. - Bull. Am. Ass. Petrol. Geol., 66, pp. 1196-1230.

Butler, R.W.H. 1982: Hanging wall strain: a function of duplex shape and footwall topography. Tectonophysics, 88, pp. 235-246.

Dahlstrom, C.D.A. 1970: Structural geology in the eastern margin of the Canadian Rocky Mountains. - Bulletin of Canadian Petroleum Geology, 18, pp. 332-406.

Dinares, J., E. McClelland, P. Santanach 1992: Contrasting rotations within thrust sheets and kinematics of thrust tectonics as derived from paleomagnetic data: an example from the Southern Pyrenees. - In: McClay, K.R. (Ed.): Thrust Tectonics. Chapman Hall, London. pp. 265-275.

Eisenstadt, G., D.G. DePaor 1987: Alternative model of thrust fault propagation. - Geology, 15, pp. 630-633.

Elliott, D. 1976: The energy balance and deformation mechanisms of thrust sheets. - Philosophical Transactions of the Royal Society, A283, pp. 289-312.

Hók, J., P. Kováč, J. Madarás, J. Maglay, M. Kováč, I. Baráth, I. Sabol, M. Slávik, M. Lukaj 1997: Neotectonic and geomorphological evolution of Slovakia. Part: Geology. - Manuscript. Archive of the Geological Institute of Dionýz Štúr Institute, Bratislava, pp. 1-77.

Jaroš, J. 1971: Tectonic styles of the homelands of superficial nappes. - Rozpravy české akadémie věd a umění, třída II (matematicko-přírodovědecká), 81, pp. 1-60.

Jolly, A.D., S.D. Sheriff 1992: Paleomagnetic study of thrust sheet motion along the Rocky Mountain front in Montana. - Bull geol. Soc. Am., 104, pp. 779-785.

Kettner, R. 1927: Preliminary report of geological survey in the Nízke Tatry Mountains. - Rozpravy České akadémie vìd a umìní, třída II (matematicko-přírodovìdecká), 36, pp. 18-31.

Kettner, R. 1931: Géologie du versant nord de la Basse Tatra dans sa partie moyenne. Guide des excursions dans les Carpathes occidentales. - State Geological Institute of Czechoslovakia Publisher, 13, pp. 373-397.

Kruczyk, J., M. Kadzialko-H ofmonkl, J. Lefeld, P. Pagáč, I. Tunyi 1992: Paleomagnetism of Jurassic sediments as evidence for oroclinal bending of the Inner Western Carpathians. Tectonophysics, 206, pp. 315-324.

Kulmanová, A., M. Rakús, A. Biely 1983: Characteristic lithostratigraphical profiles of Mesozoic of the Nízke Tatry Mountains, Part I. (the Tatric Cover Unit and the Krizná thrust). - Manuscript, Slovak Geological Survey Archive, Bratislava, pp. 1-43.

Lexa, J., V. Bezák, M. Elečko, M. Eliáš, V. Konečný, Gy. Less, G.W. Mandl, J. Mello, P. Pálenský, P. Pelikán, M. Polák, M. Potfaj, Gy. Radócz, W. Rylko, G.W. Schnábel, Z. Stráník, D. Wass, J. Vozár, T. Zelenka 2000: Geological map of Western Carpathians and adjacent areas. - Ministry of the Environment of Slovak Republic and Geological Survey of Slovak Republic Publisher, Bratislava.

Mahel', M., J. Kamenický, O. Fusán, A. Matějka 1967: Regional Geology ĖSSR, II. Western Carpathians. - Czechoslovakian Academy of Science, Praha, pp. 1-496.

Mahel', M. 1986: Geologic structure of Czechoslovak Carpathians. Paleoalpine Units. - Veda Publisher, Bratislava, pp. 5-503.

Plašienka, D. 1999: Tectochronology and Paleotectonic Model of the Jurassic-Cretaceous Evolution of the Central Western Carpathians. - Veda Publisher, SAV, Bratislava, pp. 1-125.

Suppe, J. 1983: Geometry and kinematics of fault-bend folding. - American Journal of Science 283, pp. 684-721.

Uhlig, V. 1903: Bau und Bild der Karpaten. - Bau und Bild Österreichs, Wien - Leipzig, pp. 651-911

Uhlig, V. 1907: Über die Tektonik der Karpaten. - Sitzungsber., Akad. Wiss. Mat. Nat. KI., 166, Abt. 1. Wien, pp. 126-142.

Wilkerson, M.S., S. Marshak 1997: Fold-thrust belts - an essay. - In: van der Pluijm B.A., S. Marshak (Eds): Earth Structure. WCB/McGraw-Hill, pp. 366-387. 